\title{
Infant Formula Supplemented with Biotics: Current Knowledge and Future Perspectives
}

\author{
Seppo Salminen ${ }^{1}$, Bernd Stahl ${ }^{2,3}$, Gabriel Vinderola ${ }^{4}$ and Hania Szajewska ${ }^{5, *(1)}$ \\ 1 Functional Foods Forum, Faculty of Medicine, University of Turku, 20520 Turku, Finland; \\ seppo.salminen@utu.fi \\ 2 Danone Nutricia Research, 3584 CT Utrecht, The Netherlands; bernd.stahl@danone.com \\ 3 Department of Chemical Biology \& Drug Discovery, Utrecht Institute for Pharmaceutical Sciences, \\ Utrecht University, 3584 CG Utrecht, The Netherlands \\ 4 Instituto de Lactología Industrial (INLAIN, UNL-CONICET), Facultad de Ingeniería Química, \\ Universidad Nacional del Litoral, Santiago del Estero 2829, Santa Fe 3000, Argentina; gvinde@fiq.unl.edu.ar \\ 5 Department of Paediatrics at the Medical University of Warsaw, 02091 Warsaw, Poland \\ * Correspondence: hania@ipgate.pl
}

Received: 9 June 2020; Accepted: 28 June 2020; Published: 30 June 2020

check for updates

\begin{abstract}
Breastfeeding is natural and the optimal basis of infant nutrition and development, with many benefits for maternal health. Human milk is a dynamic fluid fulfilling an infant's specific nutritional requirements and guiding the growth, developmental, and physiological processes of the infant. Human milk is considered unique in composition, and it is influenced by several factors, such as maternal diet and health, body composition, and geographic region. Human milk stands as a model for infant formula providing nutritional solutions for infants not able to receive enough mother's milk. Infant formulas aim to mimic the composition and functionality of human milk by providing ingredients reflecting those of the latest human milk insights, such as oligosaccharides, bacteria, and bacterial metabolites. The objective of this narrative review is to discuss the most recent developments in infant formula with a special focus on human milk oligosaccharides and postbiotics.
\end{abstract}

Keywords: human milk oligosaccharides; probiotics; prebiotics; synbiotics; postbiotics; $2^{\prime}$-fucosyllactose (2'-FL); lacto-N-neotetraose (LNnT); 3'-galactosyllactose (3'-GL); breastfeeding; infant formula

\section{Introduction}

Nutrition in early infancy and childhood can significantly impact growth and development as well as immediate and later health [1]. The World Health Organization recommends exclusive breastfeeding for the first six months of life, followed by continued breastfeeding with appropriate complementary foods for up to two years or beyond [2]. Breastfeeding and/or nutritional intervention during early life can help prevent both infectious and non-communicable disease risk during childhood and into adulthood [1].

A healthy gut development is of major importance during infancy. It contributes to growth and development by ensuring digestion and absorption of nutrients and fluids. The gut is also key in the development of immunity insofar as it maintains a barrier against infectious agents and interacts directly with the immune system to induce mucosal and systemic tolerance, which prevents of allergy. Furthermore, the gut provides signals to the brain to maintain a healthy state [3].

One of the major factors enabling proper gut function and development is a balanced gut microbiota [4]. Several prenatal and perinatal factors including mode of delivery, use of antibiotics, diet, and other environmental factors, including geographic region, may influence the microbial colonisation 
of the infant and in turn the maturation of the immune system, as reviewed elsewhere [5]. Hence, it is generally agreed that the gut microbiota of the healthy, full-term, vaginally delivered and breastfed infant constitutes the gold standard for a favourable microbial composition in early life [6]. Since human milk contributes remarkably to the development of a balanced gut microbiota-amongst many other health benefits - it is essential for infant formula to be as close to human milk as possible, providing bioactives targeting gut and immune health [7].

Two human milk oligosaccharides (HMOs), 2' -fucosyllactose (2'FL) and lacto-N-neotetraose (LNnT), are recent examples of optional ingredients being added to infant formula [8-11]. However, little attention has yet been given to $3^{\prime}$-galactosyllactose ( $\left.3^{\prime}-\mathrm{GL}\right)$, which is an HMO present in human milk that may also naturally occur in fermented infant formula derived by milk fermentation [12,13]. This narrative review will focus on these most recent developments in infant formula as examples of 'biotics' aiming to resemble human milk functions in infant formula.

\section{Oligosaccharides, Bacteria, and Microbial Metabolites in Human Milk}

Human milk contains many bioactive compounds such as oligosaccharides, immune cells, and varying levels of bacteria and their metabolites. They play an important role in the development of a healthy gut by supporting a favourable intestinal microbiota and in the development of the infant's immune system [14-18].

\subsection{Human Milk Oligosaccharides (HMOs)}

HMOs are pools of complex carbohydrates, the third most abundant component of human milk, and one example of naturally occurring 'prebiotics' [19]. Although originally characterised as HMOs, they are also present in the amniotic fluid, and thus the foetus is already exposed to HMOs prior to birth when ingesting the amniotic fluid [20-23].

The quantity of HMOs in mature human milk is approximately $12-15 \mathrm{~g} / \mathrm{L}$ as reported elsewhere [24,25]. There are more than 200 structurally different HMOs working together to deliver a combined beneficial effect, of which today more than 160 (neutral and acidic) types have been characterized in detail [26].

Most HMOs escape digestion in the small intestine [16] and progress to the colon acting as decoy molecules binding pathogens and getting metabolised as 'food' for the commensal gut bacteria [27], such as bifidobacteria and lactic acid bacteria, allowing such bacterial populations to become more abundant [28]. Besides their prebiotic effect, HMOs also have direct effects on immune cells [29-32], block the routes of infections [30,33], provide building blocks for the brain [34], and stimulate intestine barrier functions, as published elsewhere [35].

HMOs are synthesised in the mammary gland by the prolongation of lactose with monosaccharides forming non-digestible trisaccharides (DP3) (degree of polymerisation, which is the amount of monosaccharide building blocks) or tetrasaccharides (DP4). The addition of sialic acids leads to two different sialyllactoses (SL), 3'-SL and 6'-SL (DP3), and the addition of fucose leads to two different fucosyllactoses (FL), 2' -FL and 3-FL (DP3), as well as difucosyllactose (DP4) [25,36,37] (Figure 1).

HMOs also include galactosyllactoses (GLs), which appear in the form of several structurally distinct isomers and only differing in the glycosidic linkage of the terminal galactose added to lactose, leading to 3'-GL, 4'-GL, and 6'-GL (DP3) [38,39] (Figure 2). Those HMOs can also be derived from lactose by the enzymatic activity of bacterial $\beta$-galactosidases, which splits lactose to glucose and galactose and catalyses the transgalactosylation of lactose to produce GLs [40-43]. Using an adapted approach of a recently published targeted liquid chromatography-tandem mass spectrometry method for HMOs, native GL-isomers like 3'-GL could be directly detected in human milk samples from various stages of lactation. The abundance of $3^{\prime}-\mathrm{GL}$ appeared to be relatively stable between colostrum and mature milks, whereas 6'-GL declined over time [44]. In general, HMO concentrations decline over time from colostrum to mature milk [45], including GLs [39,46]. Thurl et al. also found a slight decrease in HMOs within the first 90 days of lactation [47]; however, this might be partly compensated for by more volume of human milk being consumed by infants in the respective longitudinal setting. 
Neutral HMOS

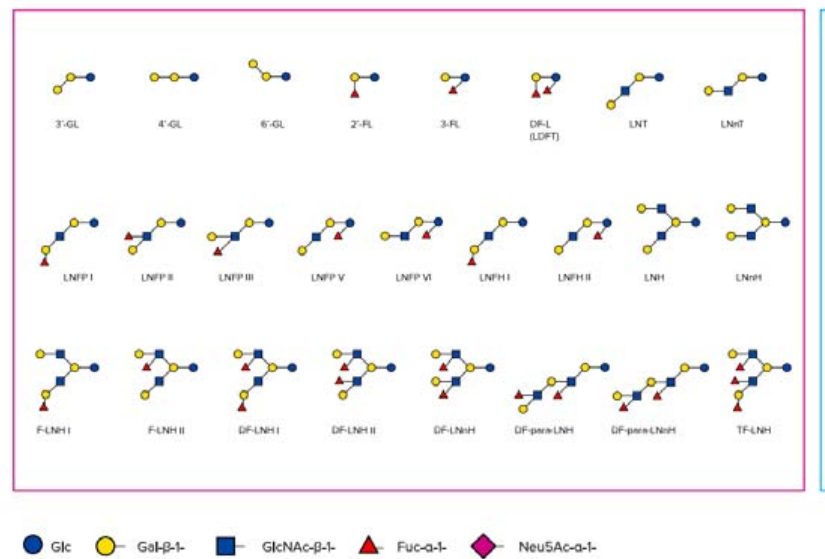

Acidic HMOS

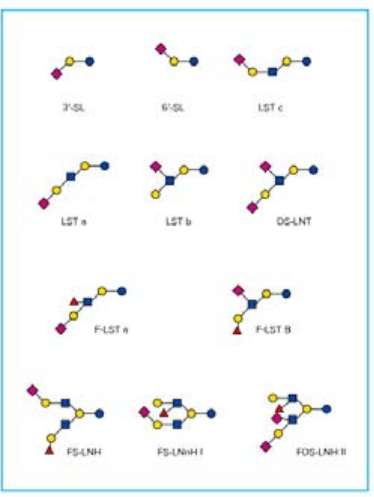

Figure 1. Chemical structure of neutral and acidic human milk oligosaccharides (HMOs) (adapted from Thurl et al. [25], Newburg et al. [38], and Urashima et al. [26]).

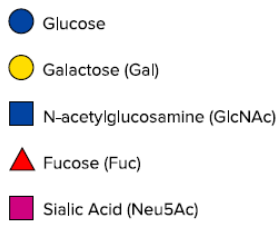

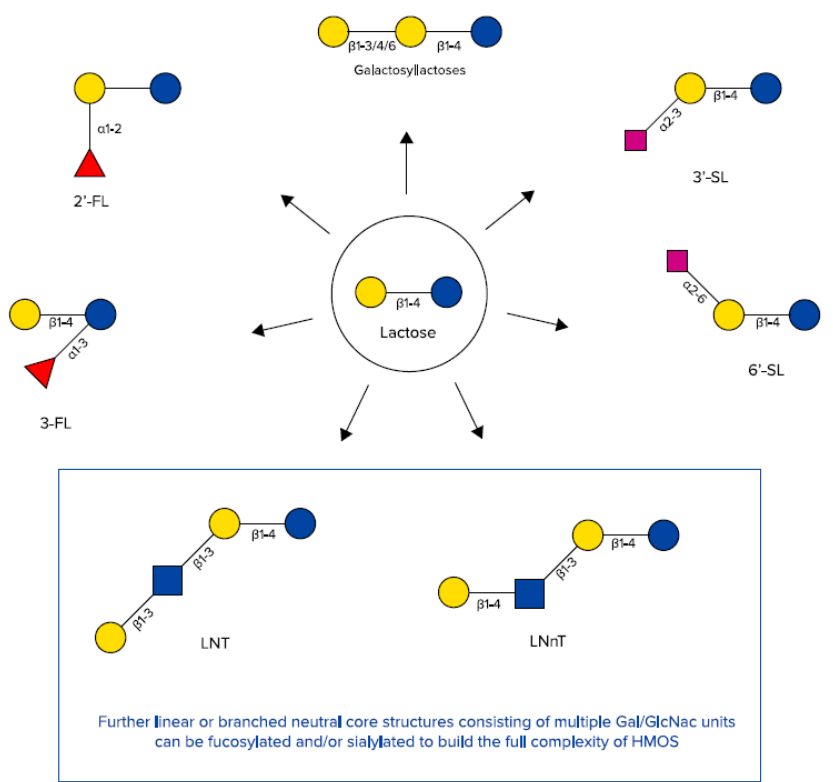

Figure 2. Chemical structures of galactosyllactoses, $2^{\prime}$-FL, 3-FL, 3'-SL, 6'-SL, Lacto-N-tetraose (LNT), and lacto-N-neotetraose (LNnT) (adapted from Urashima et al. [48]).

Larger HMO structures are derived by adding galactose and $\mathrm{N}$-actetylglucosamine as disaccharide building blocks, which leads to tetrasaccharides (DP4), Lacto-N-tetraose (LNT), and Lacto-N-neotetraose (LNnT). Those tetrasaccharides can be further extended by those disaccharide units (DP6, DP8, etc.) and in addition decorated with further single or multiple fucose residues, leading to large neutral HMOs with a molecular size up to $8 \mathrm{kDa}$ [49] and/or single or multiple sialic acid residues, leading to large acidic HMOs with a molecular size up to $3.6 \mathrm{kDa}$ [50].

Size exclusion chromatography, which was further used to describe the complexity of shortand long-chain HMOs, demonstrated a molecular size distribution of short-chain and long-chain HMOs in a ratio of 9:1 [49]. Long-chain HMOs are less easily fermented by the gut microbiota, whereas short-chain HMOs are more active in the proximal parts of the gut [26], ensuring that potential substrates are available for the gut microbiota through the gastrointestinal tract, as shown for homo-polymeric fructans [51]. 
Although the long-chain HMOs are less abundant, they may exert a relevant bioactivity, which leads to the conclusion that abundance cannot automatically explain the biological importance of a molecule.

\subsection{Bacteria in Human Milk}

Human milk is also an important source of beneficial bacteria (naturally occurring 'probiotics') that help colonise the infant gut and contribute to the composition of a favourable gut microbiota, including Bifidobacterium spp. and Lactobacillus spp. [52,53], with genus Bifidobacterium dominating the gut microbiota of a vaginally delivered infant [54,55]. Bacteria in human milk are anticipated to be bioactive components regulating the development of an infant's immune system and attenuating inflammation processes [56]. In general, the microbiome of human milk is a recent field of research, as explored elsewhere [53,56-59].

The total number of bacteria in human milk significantly differs according to detection methods. It has been estimated that human milk contains median values between $10^{3}$ and $10^{6}$ bacteria per millilitre [60-62]. The difference in number caused by different detection methods could be due to the fact that in molecular-based methods, DNA from non-viable bacteria and extracellular DNA can also be amplified, suggesting that not only live bacteria but significant amounts of non-viable bacteria coexist in human milk [60].

\subsection{Microbial Metabolites in Human Milk}

Besides bacteria, their metabolites (e.g., butyrate and other short-chain fatty acids (SCFAs), peptides, oligosaccharides) may also naturally pass into human milk, and this can be detected through metabolomics research using nuclear magnetic resonance spectroscopy $[63,64]$. Most recently these metabolites have gained more research attention that is focused on their possible role in shaping the growth and development of the infant. A widely accepted definition still needs to be agreed on, but in general, they may also be referred to as 'natural postbiotics' (comprising both inactivated bacterial cells and metabolites) and are anticipated to stimulate both healthy gut microbiota composition and function as well as immune functioning and development $[60,64,65]$.

\section{The 'Biotic' Family: Resembling Human Milk Benefits in Infant Formula}

There is increasing research on nutritional postnatal interventions using probiotics, prebiotics, synbiotics, and the so-called postbiotics to promote the establishment of a beneficial microbiota and to have a positive impact on neonatal health (Figure 3). Whereas infant formulas can only provide static selections of these substances, the amount and composition are highly dynamic and individual in human milk $[47,66,67]$. This may be illustrated by the diversity of oligosaccharide structures in human milk, which has been shown to vary among women according to genetic factors, geographical regions, stages of lactation, and, potentially, maternal probiotic supplementation during the late stages of pregnancy $[45,47,68]$. For example, in women with the active gene for fucosyltransferase 2 (FUT2, secretors), 2'-FL is by far the most abundant HMO, with a mean concentration of $2.7 \mathrm{~g} / \mathrm{L}$, and constitutes nearly $24 \%$ of all HMOs [25]. However, in the milk of women without the active gene for FUT2 (non-secretors), who make up 21\% of all women in larger parts of the world, $2^{\prime}$-FL was not found $[24,25,67]$.

According to a recent consensus definition, probiotics are live microorganisms that confer a health benefit on the host when administered in adequate amounts [69], whereas prebiotics are defined as substrates that are selectively utilised by host microorganisms conferring a health benefit [70]. An official definition of synbiotics, which are a combination of both pro- and prebiotics [71], will soon be published by the International Scientific Association for Probiotics and Prebiotics (ISAPP). In contrast to pre- and probiotics, an official aligned global definition of postbiotics is still pending and will be discussed later in this paper. 


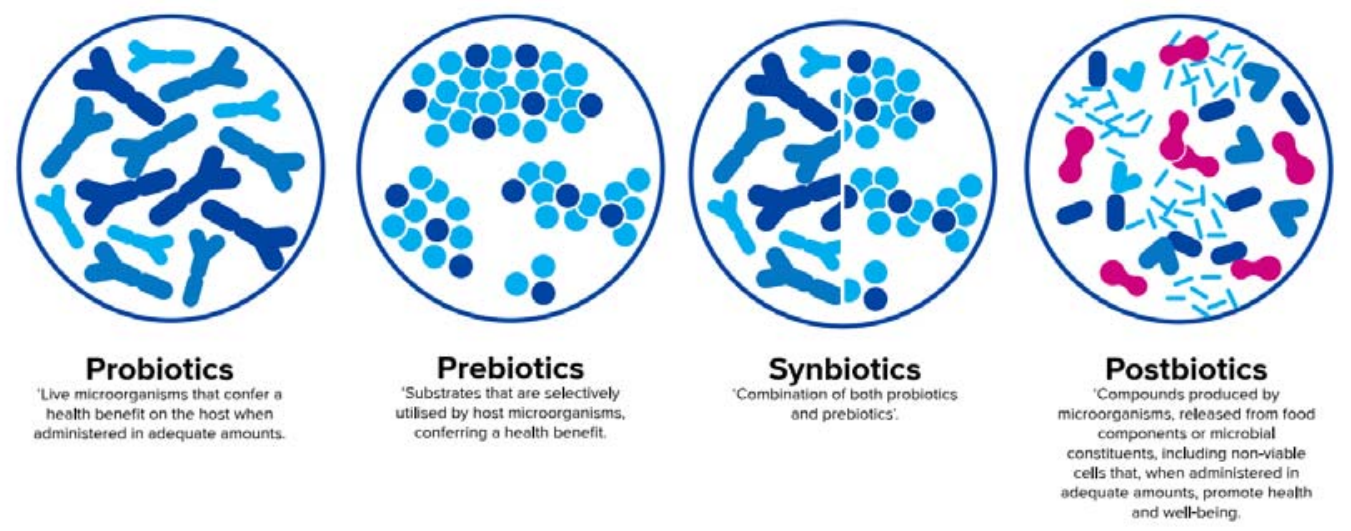

Figure 3. Definition of probiotics [69], prebiotics [70], synbiotics [71], and postbiotics [65] (adapted from Salminen et al. [72]).

\subsection{Probiotics}

Most probiotic-containing infant formula comprise Bifidobacterium spp. and/or lactic acid bacteria such as Lactobacillus spp., which are generally regarded as safe for food use in the European Union based on the QPS-list (Qualitative Presumption of Safety) of bacteria. In the United States, a non-mandatory system of safety evaluation is in place, provided by the U.S. Food \& Drug Administration (FDA). On request, it evaluates safety assessment filings of specific probiotic strains to be included in the so-called GRAS (Generally Recognized as Safe) Notice Inventory, which is continuously updated [73].

There are data on specific probiotics in infant formula accompanied by a large diversity in study outcomes [74]. However, these health benefits are very strain and disease specific. For example, for preterm infants, the Committee on Nutrition of the European Society for Paediatric Gastroenterology and Nutrition (ESPGHAN) and the ESPGHAN Working Group for Probiotics and Prebiotics conditionally recommended the use of L. rhamnosus GG (LGG) ATCC 53103 (at a daily dose ranging from $1 \times 10^{9} \mathrm{CFU}$ to $6 \times 10^{9} \mathrm{CFU}$ ) and the combination of $B$. infantis Bb-02, B. lactis Bb-12, and Str. thermophilus TH-4 (at a daily dose of 3.0 to $3.5 \times 10^{8} \mathrm{CFU}$ of each strain) as it might reduce necrotizing enterocolitis (NEC) stage 2 or 3 in preterm infants (low certainty of evidence), but mortality and sepsis did not show any clear direction in effect size. However, no recommendation could be made in either direction regarding the use of L. reuteri DSM 17938 and the combination of B. bifidum NCDO 1453 (currently reclassified as B. longum) with L. acidophilus NCDO 1748 (ATCC 4356, LA37, or NCIMB 30316) in preterm infants to reduce the risk of mortality, NEC stage 2 or 3, or sepsis (very low certainty of evidence) [75]. For term born infants, in a review from 2011, the ESPGHAN Committee on Nutrition did not recommend the routine use of probiotic- and/or prebiotic-supplemented infant formulas, identifying further need for well-designed and carefully conducted randomised controlled trials [74].

\subsection{Prebiotics}

Because of their stability, low risk of adverse effects, ease of administration, and potential for influencing the composition and function of the microbiota in the gut and beyond, the clinical applications of prebiotics are expanding [76].

In last decades, different prebiotic mixtures of galacto-oligosaccharides (GOS) and fructo-oligosaccharides (FOS) have been studied. Globally the most studied prebiotic mixture of oligosaccharides in infant formula consists of short-chain (sc) GOS and long-chain (lc) FOS, scGOS/lcFOS (9:1). The mix is in the range of HMOs close to human milk in quantity $(8 \mathrm{~g} / \mathrm{L})$ and diversity (more than 100 different structures of short- and long-chain types in a ratio of 9:1). Although this prebiotic mixture approaches the molecule size distribution of short- and long-chain oligosaccharides in human milk, it is not structurally similar to HMOs [77]. Clinical research on scGOS/lcFOS (9:1) showed benefits linked to modulation of the gut microbiota and the immune system, reduced incidence of infections, and stool 
softening [76,78,79]. This prebiotic mixture has been recognised as a prebiotic by ISAPP [70], and it may be added to infant formula and follow-on formula according to the Commission Delegated Regulation (EU) 2016/127 [80]. However, to date, there are no health claims granted by the European Food Safety Authority (EFSA) for the application of any oligosaccharides in infant formula.

In addition to prebiotics based on GOS and/or FOS, infant formulas have recently been supplemented with specific technically derived HMOs (e.g., 2'-FL and LNnT), which have been anticipated as candidate prebiotics [70] (see Section 3.3).

\subsection{Specific HMOs Added to and/or Present in Infant Formula}

Recent research highlights the variety of HMOs in human milk, underlining the importance of scientific assessment of the role of both minor and major oligosaccharides in promoting infant health before adding it to infant formula.

Technically, only 2 '-FL and LNnT are currently commercially available for addition to infant formula as purified ingredients [81]. The technology used for obtaining these is the coupling of bacterial homogenates or the utilisation of E. coli as a microbial cell factory (see Table 1). Other technologies are available but, currently, only used for analytical and research purposes. While $2^{\prime}$-FL and LNnT are obtained by chemical synthesis, $3^{\prime}$-GL occurs as a bacterial by-product during milk fermentation [12,13]. Besides these three examples, further HMOs are in the pipeline for application in infant formula [81].

Table 1. Current technologies for obtaining commercially available HMOs for application in infant formula (data on 2'FL and LNnT are adapted from Bych et al. [81], data on 3'-GL from Rodriguez-Herrera et al. [12]).

\begin{tabular}{|c|c|c|c|}
\hline HMO & Technology & Application & Ref \\
\hline \multirow{5}{*}{$2^{\prime}-\mathrm{FL}$ and $\mathrm{LNnT}$} & Isolation from human milk & $\begin{array}{l}\text { For structural identification } \\
\text { and fundamental research } \\
\text { applications only }\end{array}$ & {$[40,82-84]$} \\
\hline & $\begin{array}{l}\text { Chemo-enzymatic synthesis using } \\
\text { recombinantly expressed } \\
\text { glycosyltransferases matched with } \\
\text { nucleotide-activated donor substrates } \\
\text { and acceptors }\end{array}$ & $\begin{array}{c}\text { For generating libraries of } \\
\text { asymmetrical multi-antennary } \\
\text { HMOs for research purposes only }\end{array}$ & {$[85]$} \\
\hline & $\begin{array}{l}\text { Chemical synthesis from L-fucose, } \\
\text { D-galactose, N-acetyl-D-glucosamine, } \\
\text { and D-lactose, respectively }\end{array}$ & $\begin{array}{c}\text { Prohibitively expensive } \\
\text { for large-scale nutrition } \\
\text { applications due to complexity, } \\
\text { number of reaction steps, limited } \\
\text { availability, and high cost of raw } \\
\text { materials }\end{array}$ & [86-89] \\
\hline & $\begin{array}{c}\text { Coupling of the bacterial homogenates } \\
\text { of two or more recombinant microbial } \\
\text { cells overexpressing genes for HMO } \\
\text { synthesis }\end{array}$ & $\begin{array}{c}\text { For the industrial manufacturing } \\
\text { of LNnT and fucosylated } \\
\text { oligosaccharides }\end{array}$ & {$[90,91]$} \\
\hline & $\begin{array}{l}\text { Microbial fermentation of engineered } \\
\text { E. coli strains for fucosylation reaction } \\
\text { (complete removal of the strain and all } \\
\text { other non-desired biomolecules after } \\
\text { fermentation) }\end{array}$ & $\begin{array}{l}\text { Used for both research and viable } \\
\text { commercial production with high } \\
\text { titers of } 2^{\prime} \text {-FL and LNnT }\end{array}$ & {$[92]$} \\
\hline $3^{\prime}-\mathrm{GL}$ & $\begin{array}{l}\text { Milk fermentation process using } \\
\text { Bifidobacterium breve C50 } \\
\text { and Streptococcus thermophilus } 065 \\
\text { and providing } 3^{\prime} \text {-GL as a metabolic } \\
\text { by-product at levels of } \sim 250 \mu \mathrm{g} / \mathrm{mL}\end{array}$ & $\begin{array}{l}\text { Proprietary fermentation process } \\
\text { (Lactofidus }{ }^{\mathrm{TM}} \text { ) for large-scale } \\
\text { production of fermented } \\
\text { infant formula }\end{array}$ & {$[12]$} \\
\hline
\end{tabular}

\subsubsection{HMOs $2^{\prime}$-FL and LNnT}

2'-FL and LNnT have been anticipated as candidate prebiotics [70]. Although manufactured HMOs are structurally identical to their counterparts in human milk, regulatory approval is required 
for novel foods by the European Union (Commission Implemented Regulation (EU) 2017/2470) [93]. The EFSA Scientific Panel on Nutrition recently assessed 2'-FL, difucosyllactose (DFL), LNnT, and LNT as safe for use in infant formula [94-96]. Furthermore, $2^{\prime}-\mathrm{FL}, \mathrm{DFL}, \mathrm{LNnT}$, and LNT have been added to the GRAS-list derived from the FDA [97].

Preclinical research has shown that synthetic $2^{\prime}$-FL (with an identical structure as the 2'-FL found in human milk and often prepared from lactose) has prebiotic effects and may deliver functional benefits in infants. In preclinical trials, 2'-FL promoted the growth of specific bifidobacteria [98,99], blocked the growth of pathogens [100-102], and supported gut maturation and the stimulation of the gut intestinal barrier [103]. Furthermore, $2^{\prime}$-FL impacted neuronal dependent gut migrating motor complexes, suggesting beneficial effects on the central nervous system [104].

Infant formulas containing $2.4 \mathrm{~g}$ total oligosaccharides/L (control: scGOS only; experimental formulas: scGOS +0.2 or $1.0 \mathrm{~g} 2^{\prime}$-FL/L) have been demonstrated to be safe in terms of normal growth and were well-tolerated in a prospective, randomised, an controlled growth and tolerance study with 189 healthy, singleton infants [9]. A post-hoc analysis of this study revealed that infants receiving $0.2 \mathrm{~g} / \mathrm{L} 2^{\prime}$-FL had a significantly reduced incidence of respiratory infections as compared to the control group receiving scGOS alone. This effect was not seen in the group receiving $1.0 \mathrm{~g} / \mathrm{L} \mathrm{2}$-FL [10]. A further analysis of the same study showed that infants who received the $2^{\prime}$-FL-containing formulas had significantly lower plasma inflammatory cytokines compared to infants who received the control formula, closely resembling the levels found in the breastfed reference group, potentially indicative of an anti-inflammatory effect [8].

A recently developed infant formula concept combines a prebiotic mixture of scGOS/lcFOS (9:1) and 2'-FL to further mimic the complex composition of HMO structures and their functional benefits. Data from the first in vivo pre-clinical investigations showed positive effects of this combination in a rotavirus model [105] and in a vaccination model [32,106].

LNnT has been assessed in vitro for function as a prebiotic inducing growth and metabolic activity in Bifidobacterium infantis [107]. As an ingredient, LNnT proved to be a stable and safe component of infant formula that was evaluated for its ability to reduce oropharyngeal colonisation with Streptococcus pneumoniae in children (6 months or older). Although colonisation was not reduced, LNnT proved to be well-tolerated at the tested concentration of $200 \mathrm{mg} / \mathrm{L}$ [107].

Infant formula supplemented with a combination of $2^{\prime}$-FL $(1.0 \mathrm{~g} / \mathrm{L})$ and $\mathrm{LNnT}(0.5 \mathrm{~g} / \mathrm{L})$ was demonstrated to be safe and well-tolerated and to support age-appropriate growth in a multicentre, randomised, double-blind trial with 175 healthy infants, with weight gain as a primary study outcome. Secondary outcomes were also found including associations of lower parent-reported morbidity (particularly bronchitis) and medication use (antipyretics and antibiotics) in infants fed the supplemented formula compared to the control [11].

\subsection{2. $\mathrm{HMO} 3^{\prime}-\mathrm{GL}$}

HMO $3^{\prime}$-GL is naturally present in human milk and was already isolated from human milk in 1988 [40]. Recently, a single chromatography run using an improved sample pre-treatment method and ultrahigh pressure liquid chromatography with fluorescence detection quantified 15 sialylated and neutral HMOs with high sensitivity, identifying $3^{\prime}-\mathrm{GL}$ and $6^{\prime}-\mathrm{GL}$ in colostrum, transitional, and mature human milk [108]. Human milk from mothers with preterm delivery revealed $3^{\prime}-\mathrm{GL}$ concentrations of $4-28.82 \mu \mathrm{g} / \mathrm{mL}$ (median 10.44) at $1 \mathrm{w}$ postpartum, whereas concentrations ranged from $4-32.97 \mu \mathrm{g} / \mathrm{mL}$ (median 12.34) in colostrum and $4-20.73 \mu \mathrm{g} / \mathrm{mL}$ (median 4 ) at $8 \mathrm{w}$ postpartum from mothers with term delivery [46]. Further human milk analyses of mothers with term delivery revealed $47-79 \mu \mathrm{g} / \mathrm{mL}$ of $3^{\prime}-\mathrm{GL}$ in colostrum [109], $5.08 \pm 0.45 \mu \mathrm{g} / \mathrm{mL}$ (mean $\pm \mathrm{SD}$ ) in colostrum, and $4.84 \pm 0.48 \mu \mathrm{g} / \mathrm{mL}$ (mean $\pm \mathrm{SD}$ ) at $100 \mathrm{~d}$ of lactation [39], and $0.5-39 \mu \mathrm{g} / \mathrm{mL}$ (median 4.6) in milk pooled until $21 \mathrm{~d}$ of lactation [38].

In pre-clinical studies, $3^{\prime}-\mathrm{GL}, 4^{\prime}$-GL, and 6'-GL prepared from colostrum individually accounted for specific immunomodulation of polyinosinic:polycytodylic acid-induced interleucin-8 levels in 
an immature human intestine tested at a concentration of $200 \mu \mathrm{g} / \mathrm{mL}$ each [109]. Another study reported that a solution of $5 \mathrm{mg}$ galactosyloligosaccharides $/ \mathrm{mL}$, which was synthesized from lactose and comprised of $14 \% 3^{\prime}-\mathrm{GL}, 8 \% 4^{\prime}-\mathrm{GL}$, and $12 \% 6^{\prime}-\mathrm{GL}$, demonstrated ex vivo anti-inflammatory effects by attenuating the nuclear transcription factor $\mathrm{\kappa B}$ inflammatory signalling in human intestinal epithelial cells [38]. In a model for intestinal barrier function using human intestinal epithelial Caco-2 cell monolayers grown in a transwell system, $3^{\prime}$-GL chemically synthesised from lactose was able to protect the intestinal barrier against breakdown of intestinal integrity, whereas alpha-3'-GL (with an ג1-3 glycosidic linkage), 4'-GL, and 6'-GL (all chemically synthesized from lactose) demonstrated no significant results [110]. Previously, a commercial mixture of galacto-oligosaccharides also demonstrated a barrier-stabilising effect and resulted in improved integrity of the intestinal barrier function and reduced inflammatory response by using the same in vitro method [111].

Although these first pre-clinical data may indicate that certain galactosyllactoses, such as $3^{\prime}$-GL, have protective and immunomodulatory effects in the gut, more research is needed to further explore their role as HMOs.

Since $3^{\prime}-\mathrm{GL}$ in infant formula is a fermentation by-product, the safety of $3^{\prime}$-GL can be considered assured by the long history of safe use of the fermented formula in France [112]. The clinical evidence available on fermented infant formula is summarized in Section 3.5.3.

\subsection{Synbiotics}

Beneficial synergistic effects may be expected from a combination of probiotics and prebiotics, which are called synbiotics, using prebiotics to selectively increase abundance of both endogenous beneficial bacteria and beneficial microbes in the infant gut [113].

Given the evidence for an aberrant gut microbiota in infants with allergy $[114,115]$ and the key role of the gut microbiota on immune system maturation [116], there is a strong rationale for developing a suitable pre- and probiotic (synbiotic) blend for use in infant formula for infants at high risk of allergy and infants with already developed allergy. A synbiotic mixture of prebiotics (scGOS/lcFOS or scFOS/lcFOS in a ratio of 9:1) and the probiotic strain Bifidobacterium breve M-16V already demonstrated promising results. This synbiotic combination compensated for delayed bifidobacteria colonisation in infants delivered by caesarean section (compared to vaginally delivered infants) in an exploratory, randomised, double-blind, controlled study with 153 infants with detection of total faecal bifidobacteria as primary study outcome [117]. Secondary outcomes demonstrated a lower proportion of potential pathogens (e.g., clostridia-related species) [118], lower faecal pH, and significant changes in SCFA pattern (e.g., higher acetate and lower butyric, isobutyric, and isovaleric acids) [119]. Furthermore, this synbiotic blend led to a significant decrease of SCORAD (Scoring Atopic Dermatitis) score in infants with atopic dermatitis (AD) and greater improvement of SCORAD score in infants with IgE (immunoglobulin E)-associated AD [119]. At the 1-year follow-up of this study, children with AD in the synbiotics group showed less asthma-like symptoms (frequent wheezing and wheezing and/or noisy breathing apart from colds) and asthma medication use [120].

However, even if some synbiotic combinations already display promising clinical results in infants, more randomised trials with longer follow-up are needed for the determination of their physiological and metabolic impact on the host [113].

\subsection{Postbiotics}

In contrast to probiotics, bacterial viability in postbiotics is not seen as an essential requirement for health benefits, providing a potential opportunity to foods that are not convenient for carrying viable bacteria [121], e.g., liquid infant formula.

In infant formulas, the concept of postbiotics is yet to be defined, although specific fermented infant formulas with postbiotics have been commercially available in Europe for decades. So far, most known postbiotics are derived from Lactobacillus and Bifidobacterium strains, which are also generally the most used probiotics [65]. 


\subsubsection{Definition of Postbiotics}

Recently, a provisional definition has been formulated that stipulates that postbiotics are compounds produced by microorganisms and released from food components or microbial constituents, including non-viable cells that, when administered in adequate amounts, promote health and well-being [65].

Examples of postbiotics have been summarised as follows [65]:

- Compounds deriving from bacterial metabolism, such as exopolysaccharides, vitamins, lactic acid, bacteriocins, enzymes, surfactants, antioxidants, and SCFAs.

- Complex molecules released from food compounds (enzymatically produced during food fermentation), such as peptides and galacto-oligosaccharides, e.g., 3'-GL and 6'-GL.

- Components released from lysed cells including DNA, RNA, cell walls and, perhaps, other cytoplasmic components, and surface layer proteins.

A consensus definition on postbiotics is currently being formulated by ISAPP [122].

\subsubsection{Postbiotics through Fermentation}

For many thousands of years, fermentation of food has been applied as a natural process to generate foods with particular properties, palatability, taste, and health benefits [113]. Most health benefits of fermented functional foods are accomplished by either the live microorganisms ingested or by postbiotics deriving from these microorganisms [65].

For cow's milk-based infant formulas, fermentation processes typically use lactic acid-producing bacteria as a starter culture [65]. In addition to lactose consumption during fermentation, microbial enzymatic transgalactosylation can transform lactose into other lactose-based biomolecules, with $3^{\prime}$-GL as the major trisaccharide produced by Streptococcus thermophilus (e.g., Streptococcus thermophilus 065) from lactose fermentation [13]. The fermentation process is usually followed by physical treatment, which may include homogenisation, pasteurisation, sterilisation, and/or spray-drying [123].

Recently, a specific fermentation process has been developed for infant nutrition, using two specific types of food-grade lactic acid producing microorganisms (Bifidobacterium breve $\mathrm{C} 50$ and Streptococcus thermophilus 065 ) and naturally delivering postbiotics $[12,124,125]$.

\subsubsection{Benefits of Postbiotics in Infant Formula}

In a mouse model, infant formula containing postbiotics deriving from a specific fermentation process combined with prebiotic scGOS/lcFOS (9:1) stimulated morphological (i.e., crypt villus length in ileum) and functional (i.e., ileal sucrase activity, gut permeability) gut maturation more similar to the mother-fed situation than infant formula without pre- or postbiotics [126]. Gut permeability measured by fluorescein isothiocyanate-dextran was similar in mice receiving post- and prebiotics and mother-fed mice, while it was significantly lower in mice receiving the control infant formula without post- or prebiotics (Figure 4). An early decrease in permeability, as observed in the control group, could have a lasting detrimental effect on health by changing immune maturation [127]. 


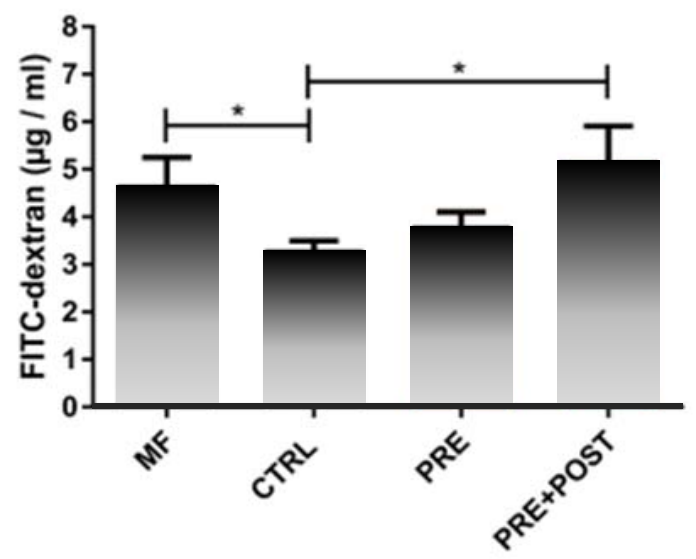

Figure 4. Gut permeability measured by fluorescein isothiocyanate (FITC)-dextran in mice fed infant formula (IF) containing postbiotics deriving from a specific fermentation process (Lactofidus ${ }^{\mathrm{TM}}$ ) and prebiotic scGOS/lcFOS (9:1) (PRE+POST) compared to IF with prebiotics only (PRE), control IF without post- and prebiotics (CTRL), and mother-fed mice (MF); data represent mean + standard error of the mean (SEM); one-way ANOVA + post-test; * $p \leq 0.05$ [126]. Results derive from a congress abstract and are currently in preparation for full publication. Courtesy of Dr A. Vincent, Dr I. Renes and Dr I. Van Seuningen.

The first clinical study with a fermented infant formula was already published in 1989, reporting positive effects on gut function [128]. More recently, specific postbiotics deriving from fermentation have been reported to positively affect the gut microbiota, metabolic pathways, and immune responses $[4,129,130]$.

Specifically, an infant formula fermented by Bifidobacterium breve C50 and Streptococcus thermophilus 065-with and without prebiotic scGOS/lcFOS (9:1)—demonstrated its capacity to impact immune and gut health benefits in otherwise healthy infants (Table 2). Since fermented formulas may consist of a variety of bacterial metabolites, their benefits cannot be attributed to any single metabolite alone.

In a recent systematic review, limited evidence was demonstrated for specific postbiotics being recommended for treating paediatric diarrhoea and preventing common infectious diseases among children. For therapeutic trials, supplementation with heat-inactivated Lactobacillus acidophilus LB reduced the duration of diarrhoea, and for preventive trials, heat-inactivated Lactobacillus paracasei CBA L74 reduced the risk of diarrhoea, pharyngitis, and laryngitis [131].

In view of the suggested preclinical and clinical results, postbiotics should be considered as strain-specific as probiotics: each bacterial strain and each fermentation process generate unique cells, cell structures, and metabolites with varying functionalities, and the benefits need to be established according to the defined combination of the compounds. 
Table 2. Impact of infant formula fermented with Bifidobacterium breve C50 and Streptococcus thermophilus 065 on immune and gut parameters.

\begin{tabular}{|c|c|c|c|c|}
\hline Infants & Duration (and Start) of Diet & Diet (No. of Infants) & Impact (Fermented vs. Standard Formula Group) & Ref \\
\hline \multicolumn{5}{|c|}{ Impact on immune parameters } \\
\hline Healthy infants & $4 \mathrm{~m}$ (from birth) & Fermented (11) vs. standard formula (9) & $\begin{array}{l}\text { Higher faecal IgA response to polio vaccine } \\
\text { Reduced severity of }\end{array}$ & [132] \\
\hline Healthy infants & $5 \mathrm{~m}$ (from $4-6 \mathrm{~m}$ of age) & Fermented (464) vs. standard formula (449) & $\begin{array}{l}\text { acute diarrhoea (no effect on incidence and duration of } \\
\text { diarrhoea episodes and number of hospital admissions) }\end{array}$ & [133] \\
\hline Healthy infants & $4 \mathrm{~m}$ (from birth) & Fermented (30) vs. standard formula (30); HM (30) & $\begin{array}{c}\text { Enhanced thymus size (fermented formula group } \\
\text { closer to HM) }\end{array}$ & [134] \\
\hline Preterm infants $(\mathrm{GA}<35 \mathrm{w})$ & $2-5 \mathrm{w}$ (from birth) & Fermented (21) vs. standard formula (31) & $\begin{array}{l}\text { Lower faecal calprotectin and higher secretory IgA (no } \\
\text { effect on TNF- } \alpha \text { ) }\end{array}$ & [135] \\
\hline Infants at high risk of atopy & $12 \mathrm{~m}$ (from birth) & Fermented (66) vs. standard formula (63) & $\begin{array}{l}\text { Less positive SPT to cow's milk (no effect on CMA } \\
\text { incidence) and lower incidence of digestive } \\
\text { and respiratory potentially allergic AEs }\end{array}$ & [136] \\
\hline
\end{tabular}

(fermented formula ${ }^{1}$ additionally contained prebiotic scGOS/lcFOS (9:1))

Softer stool consistency (fermented formula group

$$
\text { closer to HM) }
$$

Healthy infants

From 0-28 d until $17 \mathrm{w}$ of life

Fermented (77) vs. standard formula (86); HM (90)

No differences regarding parent-reported GI

(and related) symptoms and investigator-reported AEs

(except lower incidence of infantile colic)

Stools: lower $\mathrm{pH}$, higher levels of acetic acid and sIgA,

increased Bifidobacterium sp, and decreased

Clostridium difficile occurrence (gut microbiota

Subset of 30 infants per study arm composition of fermented formula group closer to HM)

${ }^{1}$ Based on a recently developed fermentation process (Lactofidus ${ }^{\mathrm{TM}}$ ) generating bioactive compounds; one of these was $3^{\prime}$-GL at a level of $\sim 250 \mu \mathrm{g} / \mathrm{mL}$. Abbreviations: AE (adverse event), CMA (cow's milk allergy), GA (gestational age), GI (gastrointestinal), HM (human milk), IgA (immunoglobulin A), SPT (skin prick test). Reference [137] is a congress abstract and is currently in preparation for full publication. 


\section{Conclusions}

Breastfeeding is the natural and optimal way of feeding an infant. Current research still focuses on infant formula aiming to more closely resemble the composition and functionality of human milk, with some already comprising probiotics, prebiotics, synbiotics, and postbiotics. Human milk naturally provides these components by delivering HMOs ('natural prebiotics') and beneficial bacteria ('natural probiotics') and their metabolites ('natural postbiotics'). In infant formula, these nutritional concepts are provided by different pre- and probiotic mixtures and a mixture of both (synbiotics) and, additionally, by using partly fermented infant formula with beneficial compounds produced by microorganisms that are released from food components or microbial constituents, including non-viable cells (postbiotics). One of the most current examples of such compounds is $3^{\prime}$-galactosyllactose ( $3^{\prime}$-GL), which is present in human milk and is a natural derivative of milk fermentation. Although such developments may pave the way for future infant formula alternatives for those infants who are not able to be (fully) breastfed, human milk feeding will always remain the unmatched goal for infant nutrition and development as well as provide many benefits for maternal health.

Author Contributions: S.S. and H.S. wrote, reviewed, and edited the manuscript. B.S. reviewed and edited the manuscript (in particular the biological aspects and health benefits of HMOs). G.V. reviewed and edited the manuscript (in particular the technological aspects of HMO production). All authors have read and agreed to the published version of the manuscript.

Funding: This research received no external funding.

Acknowledgments: The authors are grateful to Jan Knol (Laboratory of Microbiology, Wageningen University, 6708 WE Wageningen, The Netherlands), Johan Garssen (Division of Pharmacology, Utrecht Institute for Pharmaceutical Sciences, Faculty of Science, Utrecht University, 3584 CA Utrecht, The Netherlands), and Marko Mank for their support and scientific expertise. All three are employees of Danone Nutricia Research, 3584 CT Utrecht, The Netherlands.

Conflicts of Interest: B.S. is employee of Danone Nutricia Research, which has proprietary rights to the prebiotic mixture of scGOS/lcFOS (9:1), mentioned in Section 3.2, and to the fermentation process Lactofidus ${ }^{\mathrm{TM}}$, mentioned in Section 3.5.2 and in Tables 1 and 2. All other authors declare no conflict of interest.

\section{Abbreviations}

$\begin{array}{ll}2^{\prime}-\mathrm{FL} & 2 \text { '-fucosyllactose } \\ 3^{\prime}-\mathrm{GL} & 3^{\prime} \text {-galactosyllactose } \\ 4^{\prime}-\mathrm{GL} & 4^{\prime} \text {-galactosyllactose } \\ \text { AD } & \text { atopic dermatitis } \\ \text { AE } & \text { adverse event } \\ \text { ATCC } & \text { American Type Culture Collection } \\ \text { DFL } & \text { difucosyllactose } \\ \text { DP } & \text { degree of polymerisation } \\ \text { Caco } & \text { adenocarcinoma of the colon } \\ \text { CBA } & \text { chocolate blood agar } \\ \text { CFU } & \text { colony forming units } \\ \text { CMA } & \text { cow's milk allergy } \\ \text { DNA } & \text { deoxyribonucleic acid } \\ \text { DSM } & \text { Dutch State Mines } \\ \text { EFSA } & \text { European Food Safety Authority } \\ \text { ESPGHAN } & \text { European Society for Paediatric Gastroenterology, Hepatology and Nutrition } \\ \text { FDA } & \text { U.S. Food \& Drug Administration } \\ \text { FL } & \text { fucosyllactoses } \\ \text { FOS } & \text { fructo-oligosacharides } \\ \text { FUT2 } & \text { fucosyltransferase 2 }\end{array}$




$\begin{array}{ll}\text { GOS } & \text { galacto-oligosaccharides } \\ \text { GL } & \text { galactosyllactose } \\ \text { GRAS } & \text { generally recognized as safe } \\ \text { HM } & \text { human milk } \\ \text { HMO } & \text { human milk oligosaccharide } \\ \text { IF } & \text { infant formula } \\ \text { IgE } & \text { immunoglobulin E } \\ \text { ISAPP } & \text { International Scientific Association for Probiotics and Prebiotics } \\ \text { kDa } & \text { kilodalton } \\ \text { LA } & \text { Lactobacillus acidophilus } \\ \text { LB } & \text { lysogeny broth } \\ \text { LNnT } & \text { lacto-N-neotetraose } \\ \text { LNT } & \text { lacto-N-tetraose } \\ \text { NCDO } & \text { National Collection of Dairy Organism } \\ \text { NCIMB } & \text { National Collection of Industrial, Food and Marine Bacteria } \\ \text { NEC } & \text { necrotizing enterocolitis } \\ \text { QPS } & \text { qualitative presumption of safety } \\ \text { RNA } & \text { ribonucleic acid } \\ \text { SCORAD } & \text { scoring atopic dermatitis } \\ \text { scGOS/lcFOS (9:1) } & \text { short-chain GOS/long-chain FOS (in a ratio of 9:1) } \\ \text { SCFA } & \text { short-chain fatty acid } \\ \text { SEM } & \text { standard error of the mean } \\ \text { SL } & \text { sialyllactose } \\ \text { spp } & \text { subspecies } \\ & \end{array}$

\section{References}

1. Thurow, R. The First 1,000 Days: A Crucial Time for Mothers and Children-And the World. Breastfeed. Med. 2016, 11, 416-418. [CrossRef]

2. Victora, C.G.; Bahl, R.; Barros, A.J.D.; A França, G.V.; Horton, S.; Krasevec, J.; Murch, S.; Sankar, M.J.; Walker, N.; Rollins, N.C. Breastfeeding in the 21st century: Epidemiology, mechanisms, and lifelong effect. Lancet 2016, 387, 475-490. [CrossRef]

3. Bischoff, S.C. 'Gut health': A new objective in medicine? BMC Med. 2011, 9, 24. [CrossRef] [PubMed]

4. Martin, R.; Nauta, A.J.; Ben Amor, K.; Knippels, L.M.; Knol, J.; Garssen, J. Early life: Gut microbiota and immune development in infancy. Benef. Microbes 2010, 1, 367-382. [CrossRef] [PubMed]

5. Dzidic, M.; Boix-Amorós, A.; Selma-Royo, M.; Mira, A.; Collado, M.C. Gut Microbiota and Mucosal Immunity in the Neonate. Med. Sci. 2018, 6, 56. [CrossRef]

6. Collado, M.C.; Cernada, M.; Baüerl, C.; Vento, M.; Pérez-Martínez, G. Microbial ecology and host-microbiota interactions during early life stages. Gut Microbes 2012, 3, 352-365. [CrossRef]

7. Oozeer, R.; Rescigno, M.; Ross, R.P.; Knol, J.; Blaut, M.; Khlebnikov, A.; Dore, J. Gut health: Predictive biomarkers for preventive medicine and development of functional foods. Br. J. Nutr. 2010, 103, 1539-1544. [CrossRef]

8. Goehring, K.C.; Marriage, B.J.; Oliver, J.S.; A Wilder, J.; Barrett, E.G.; Buck, R.H. Similar to Those Who Are Breastfed, Infants Fed a Formula Containing 2'-Fucosyllactose Have Lower Inflammatory Cytokines in a Randomized Controlled Trial. J. Nutr. 2016, 146, 2559-2566. [CrossRef] [PubMed]

9. Marriage, B.J.; Buck, R.H.; Goehring, K.C.; Oliver, J.S.; Williams, J.A. Infants Fed a Lower Calorie Formula With 2'FL Show Growth and 2'FL Uptake Like Breast-Fed Infants. J. Pediatr. Gastroenterol. Nutr. 2015, 61, 649-658. [CrossRef]

10. Reverri, E.J.; Devitt, A.A.; Kajzer, J.A.; Baggs, G.; Borschel, M.W. Review of the Clinical Experiences of Feeding Infants Formula Containing the Human Milk Oligosaccharide 2'-Fucosyllactose. Nutrients 2018, 10, 1346. [CrossRef]

11. Puccio, G.; Alliet, P.; Cajozzo, C.; Janssens, E.; Corsello, G.; Sprenger, N.; Wernimont, S.; Egli, D.; Gosoniu, L.; Steenhout, P. Effects of Infant Formula With Human Milk Oligosaccharides on Growth and Morbidity: A Randomized Multicenter Trial. J. Pediatr. Gastroenterol. Nutr. 2017, 64, 624-631. [CrossRef] [PubMed] 
12. Rodriguez-Herrera, A.; Mulder, K.; Bouritius, H.; Rubio, R.; Muñoz-Hoyos, A.; Agosti, M.; Lista, G.; Corvaglia, L.; Ludwig, T.; Abrahamse-Berkeveld, M.; et al. Gastrointestinal Tolerance, Growth and Safety of a Partly Fermented Formula with Specific Prebiotics in Healthy Infants: A Double-Blind, Randomized, Controlled Trial. Nutrients 2019, 11, 1530. [CrossRef] [PubMed]

13. Perrin, V.; Fenet, B.; Praly, J.-P.; Lecroix, F.; Ta, C.D. Identification and synthesis of a trisaccharide produced from lactose by transgalactosylation. Carbohydr. Res. 2000, 325, 202-210. [CrossRef]

14. Ayechu-Muruzabal, V.; Van Stigt, A.H.; Mank, M.; Willemsen, L.E.M.; Stahl, B.; Garssen, J.; Land, B.V. Diversity of Human Milk Oligosaccharides and Effects on Early Life Immune Development. Front. Pediatr. 2018, 6, 239. [CrossRef]

15. Bergmann, H.; Rodríguez, J.M.; Salminen, S.; Szajewska, H. Probiotics in human milk and probiotic supplementation in infant nutrition: A workshop report. Br. J. Nutr. 2014, 112, 1119-1128. [CrossRef]

16. Engfer, M.B.; Stahl, B.; Finke, B.; Sawatzki, G.; Daniel, H. Human milk oligosaccharides are resistant to enzymatic hydrolysis in the upper gastrointestinal tract. Am. J. Clin. Nutr. 2000, 71, 1589-1596. [CrossRef]

17. Fernández, L.; Langa, S.; Martín, V.; Jiménez, E.; Martín, R.; Rodríguez, J.M. The microbiota of human milk in healthy women. Cell. Mol. Biol. 2013, 59, 31-42.

18. Andreas, N.J.; Kampmann, B.; Le Doare, K. Human breast milk: A review on its composition and bioactivity. Early Hum. Dev. 2015, 91, 629-635. [CrossRef]

19. Wegh, C.A.; Geerlings, S.Y.; Knol, J.; Roeselers, G.; Belzer, C. Postbiotics and Their Potential Applications in Early Life Nutrition and Beyond. Int. J. Mol. Sci. 2019, 20, 4673. [CrossRef]

20. Aakko, J.; Kumar, H.; Rautava, S.; Wise, A.; Autran, C.; Bode, L.; Isolauri, E.; Salminen, S. Human milk oligosaccharide categories define the microbiota composition in human colostrum. Benef. Microbes 2017, 8, 563-567. [CrossRef]

21. Wise, A.; Robertson, B.; Choudhury, B.; Rautava, S.; Isolauri, E.; Salminen, S.; Bode, L. Infants Are Exposed to Human Milk Oligosaccharides Already in utero. Front. Pediatr. 2018, 6, 270. [CrossRef] [PubMed]

22. Hirschmugl, B.; Brandl, W.; Csapo, B.; Van Poppel, M.N.M.; Köfeler, H.C.; Desoye, G.; Wadsack, C.; Jantscher-Krenn, E. Evidence of Human Milk Oligosaccharides in Cord Blood and Maternal-to-Fetal Transport across the Placenta. Nutrients 2019, 11, 2640. [CrossRef]

23. Jantscher-Krenn, E.; Aigner, J.; Reiter, B.; Köfeler, H.C.; Csapo, B.; Desoye, G.; Bode, L.; Van Poppel, M.N.M. Evidence of human milk oligosaccharides in maternal circulation already during pregnancy: A pilot study. Am. J. Physiol. Endocrinol. Metab. 2019, 316, E347-E357. [CrossRef] [PubMed]

24. Thurl, S.; Henker, J.; Siegel, M.; Tovar, K.; Sawatzki, G. Detection of four human milk groups with respect to Lewis blood group dependent oligosaccharides. Glycoconj. J. 1997, 14, 795-799. [CrossRef] [PubMed]

25. Thurl, S.; Munzert, M.; Boehm, G.; Matthews, C.; Stahl, B. Systematic review of the concentrations of oligosaccharides in human milk. Nutr. Rev. 2017, 75, 920-933. [CrossRef] [PubMed]

26. Urashima, T.; Hirabayashi, J.; Sato, S.; Kobata, A. Human Milk Oligosaccharides as Essential Tools for Basic and Application Studies on Galectins. Trends Glycosci. Glycotechnol. 2018, 30, SJ11-SJ24. [CrossRef]

27. Bode, L. Human milk oligosaccharides: Every baby needs a sugar mama. Glycobiology 2012, 22, 1147-1162. [CrossRef]

28. Walker, W.A.; Iyengar, R.S. Breast milk, microbiota, and intestinal immune homeostasis. Pediatr. Res. 2014, 77, 220-228. [CrossRef]

29. Bode, L.; Kunz, C.; Muhly-Reinholz, M.; Mayer, K.; Seeger, W.; Rudloff, S. Inhibition of monocyte, lymphocyte, and neutrophil adhesion to endothelial cells by human milk oligosaccharides. Thromb. Haemost. 2004, 92, 1402-1410. [CrossRef]

30. Eiwegger, T.; Stahl, B.; Haidl, P.; Schmitt, J.; Boehm, G.; Dehlink, E.; Urbanek, R.; Szépfalusi, Z. Prebiotic oligosaccharides: In vitro evidence for gastrointestinal epithelial transfer and immunomodulatory properties. Pediatr. Allergy Immunol. 2010, 21, 1179-1188. [CrossRef]

31. Eiwegger, T.; Stahl, B.; Schmitt, J.; Boehm, G.; Gerstmayr, M.; Pichler, J.; Dehlink, E.; Loibichler, C.; Urbanek, R.; Szepfalusi, Z.; et al. Human Milk-Derived Oligosaccharides and Plant-Derived Oligosaccharides Stimulate Cytokine Production of Cord Blood T-Cells In Vitro. Pediatr. Res. 2004, 56, 536-540. [CrossRef] [PubMed]

32. Xiao, L.; Engen, P.; Leusink-Muis, T.; Van Ark, I.; Stahl, B.; A Overbeek, S.; Garssen, J.; Naqib, A.; Green, S.J.; Keshavarzian, A.; et al. The Combination of 2'-Fucosyllactose with Short-Chain Galacto-Oligosaccharides and Long-Chain Fructo-Oligosaccharides that Enhance Influenza Vaccine Responses Is Associated with Mucosal Immune Regulation in Mice. J. Nutr. 2019, 149, 856-869. [CrossRef] [PubMed] 
33. Newburg, D.S.; Ruiz-Palacios, G.M.; Altaye, M.; Chaturvedi, P.; Meinzen-Derr, J.; Guerrero, M.D.L.; Morrow, A.L. Innate protection conferred by fucosylated oligosaccharides of human milk against diarrhea in breastfed infants. Glycobiology 2003, 14, 253-263. [CrossRef] [PubMed]

34. Wang, S.; Harvey, L.; Martin, R.; Van Der Beek, E.M.; Knol, J.; Cryan, J.F.; Renes, I. Targeting the gut microbiota to influence brain development and function in early life. Neurosci. Biobehav. Rev. 2018, 95, 191-201. [CrossRef] [PubMed]

35. Cheng, L.; Akkerman, R.; Kong, C.; Walvoort, M.T.C.; De Vos, P. More than sugar in the milk: Human milk oligosaccharides as essential bioactive molecules in breast milk and current insight in beneficial effects. Crit. Rev. Food Sci. Nutr. 2020, 1-17. [CrossRef] [PubMed]

36. Urashima, T.; Asakuma, S.; Leo, F.; Fukuda, K.; Messer, M.; Oftedal, O.T. The Predominance of Type I Oligosaccharides Is a Feature Specific to Human Breast Milk123. Adv. Nutr. 2012, 3, 473S-482S. [CrossRef] [PubMed]

37. Kobata, A. Structures and functions of the sugar chains of glycoproteins. JBIC J. Boil. Inorg. Chem. 1992, 209, 483-501. [CrossRef]

38. Newburg, D.; Ko, J.S.; Leone, S.; Nanthakumar, N.N. Human Milk Oligosaccharides and Synthetic Galactosyloligosaccharides Contain 3'-, 4-, and 6'-Galactosyllactose and Attenuate Inflammation in Human T84, NCM-460, and H4 Cells and Intestinal Tissue Ex Vivo. J. Nutr. 2015, 146, 358-367. [CrossRef]

39. Sumiyoshi, W.; Urashima, T.; Nakamura, T.; Arai, I.; Nagasawa, T.; Saito, T.; Tsumura, N.; Wang, B.; Brand-Miller, J.; Watanabe, Y.; et al. Galactosyllactoses in the Milk of Japanese Women: Changes in Concentration during the Course of Lactation. J. Appl. Glycosci. 2004, 51, 341-344. [CrossRef]

40. Donald, A.S.; Feeney, J. Separation of human milk oligosaccharides by recycling chromatography. First isolation of lacto-N-neo-difucohexaose II and 3'-galactosyllactose from this source. Carbohydr. Res. 1988, 178, 79-91. [CrossRef]

41. Gänzle, M.G.; Haase, G.; Jelen, P. Lactose: Crystallization, hydrolysis and value-added derivatives. Int. Dairy J. 2008, 18, 685-694. [CrossRef]

42. Sugawara, M.; Idota, T. A new oligosaccharide: 4'-galactosyllactose in human milk. In Proceedings of the Annual Meeting of Japan Society for Bioscience, Biotechnology, and Agrochemistry, Tokyo, Japan, 3 August 1995; p. 132.

43. Yamashita, K.; Kobata, A. Oligosaccharides of human milk. Isolation and characterization of a new trisaccharide, 6'-galactosyllactose. Arch. Biochem. Biophys. 1974, 174, 582-591. [CrossRef]

44. Mank, M.; Blijenberg, B.; Stahl, B. Label free targeted LC-ESI-MS2 analysis of $3^{\prime}$ - and 6'-galactosyllactose in human milk with enhanced structural selectivity. J. Pediatr. Gastroenterol. Nutr. 2019, 68, N-P-126.

45. Coppa, G.; Pierani, P.; Zampini, L.; Carloni, I.; Carlucci, A.; Gabrielli, O. Oligosaccharides in human milk during different phases of lactation. Acta Paediatr. 1999, 88, 89-94. [CrossRef]

46. Austin, S.; De Castro, C.A.; Sprenger, N.; Affolter, M.; Affolter, M.; Garcia-Rodenas, C.L.; Beauport, L.; Tolsa, J.-F.; Fumeaux, C.J.F. Human Milk Oligosaccharides in the Milk of Mothers Delivering Term versus Preterm Infants. Nutrients 2019, 11, 1282. [CrossRef]

47. Thurl, S.; Munzert, M.; Henker, J.; Boehm, G.; Müller-Werner, B.; Jelinek, J.; Stahl, B. Variation of human milk oligosaccharides in relation to milk groups and lactational periods. Br. J. Nutr. 2010, 104, 1261-1271. [CrossRef] [PubMed]

48. Urashima, T.; Kitaoka, M.; Terabayashi, T.; Fukuda, K.; Ohnishi, M.; Kobata, A. Milk oligosaccharides. In Oligosaccharides: Sources, Properties and Applications; Gordon, N.S., Ed.; Nova Science Publishers: Hauppauge, NY, USA, 2011.

49. Stahl, B.; Thurl, S.; Zeng, J.; Karas, M.; Hillenkamp, F.; Steup, M.; Sawatzki, G. Oligosaccharides from Human Milk as Revealed by Matrix-Assisted Laser Desorption/Ionization Mass Spectrometry. Anal. Biochem. 1994, 223, 218-226. [CrossRef]

50. Finke, B.; Stahl, B.; Pfenninger, A.; Karas, M.; Daniel, H.; Sawatzki, G. Analysis of high-molecular-weight oligosaccharides from human milk by liquid chromatography and MALDI-MS. Anal. Chem. 1999, 71, 3755-3762. [CrossRef]

51. Van De Wiele, T.; Boon, N.; Possemiers, S.; Jacobs, H.; Verstraete, W. Inulin-type fructans of longer degree of polymerization exert more pronounced in vitro prebiotic effects. J. Appl. Microbiol. 2007, 102, 452-460. [CrossRef] 
52. Jeurink, P.; Van Bergenhenegouwen, J.; Jiménez, E.; Knippels, L.; Fernández, L.; Garssen, J.; Knol, J.; Rodríguez, J.M.; Martin, R. Human milk: A source of more life than we imagine. Benef. Microbes 2013, 4, 17-30. [CrossRef]

53. Witkowska-Zimny, M.; Kaminska-El-Hassan, E. Cells of human breast milk. Cell. Mol. Boil. Lett. 2017, $22,11$. [CrossRef]

54. Reyman, M.; Van Houten, M.A.; Van Baarle, D.; Bosch, A.A.T.M.; Man, W.H.; Chu, M.L.J.N.; Arp, K.; Watson, R.L.; Sanders, E.A.M.; Fuentes, S.; et al. Impact of delivery mode-associated gut microbiota dynamics on health in the first year of life. Nat. Commun. 2019, 10, 4997. [CrossRef] [PubMed]

55. Underwood, M.A.; German, J.B.; Lebrilla, C.B.; Mills, D.A. Bifidobacterium longum subspecies infantis: Champion colonizer of the infant gut. Pediatr. Res. 2014, 77, 229-235. [CrossRef]

56. Thai, J.D.; Gregory, K.E. Bioactive Factors in Human Breast Milk Attenuate Intestinal Inflammation during Early Life. Nutrients 2020, 12, 581. [CrossRef] [PubMed]

57. Lackey, K.A.; Williams, J.E.; Meehan, C.L.; Zachek, J.A.; Benda, E.D.; Price, W.J.; Foster, J.A.; Sellen, D.W.; Kamau-Mbuthia, E.W.; Kamundia, E.W.; et al. What's Normal? Microbiomes in Human Milk and Infant Feces Are Related to Each Other but Vary Geographically: The INSPIRE Study. Front. Nutr. 2019, 6, 45. [CrossRef] [PubMed]

58. Rodríguez, J.M. The origin of human milk bacteria: Is there a bacterial entero-mammary pathway during late pregnancy and lactation? Adv. Nutr. 2014, 5, 779-784. [CrossRef]

59. Pärnänen, K.M.M.; Karkman, A.; Hultman, J.; Lyra, C.; Bengtsson-Palme, J.; Larsson, D.G.J.; Rautava, S.; Isolauri, E.; Salminen, S.; Kumar, H.; et al. Maternal gut and breast milk microbiota affect infant gut antibiotic resistome and mobile genetic elements. Nat. Commun. 2018, 9, 3891. [CrossRef]

60. Boix-Amorós, A.; Collado, M.C.; Mira, A. Relationship between Milk Microbiota, Bacterial Load, Macronutrients, and Human Cells during Lactation. Front. Microbiol. 2016, 7, 3389. [CrossRef]

61. Heikkila, M.; Saris, P.E.J. Inhibition of Staphylococcus aureus by the commensal bacteria of human milk. J. Appl. Microbiol. 2003, 95, 471-478. [CrossRef]

62. Gueimonde, M.; Laitinen, K.; Salminen, S.; Isolauri, E. Breast Milk: A Source of Bifidobacteria for Infant Gut Development and Maturation? Neonatology 2007, 92, 64-66. [CrossRef]

63. Bardanzellu, F.; Fanos, V.; Strigini, F.A.L.; Artini, P.G.; Peroni, D.G. Human Breast Milk: Exploring the Linking Ring Among Emerging Components. Front. Pediatr. 2018, 6. [CrossRef] [PubMed]

64. Gómez-Gallego, C.; Morales, J.M.; Monleon, D.; Du Toit, E.; Kumar, H.; Linderborg, K.M.; Zhang, Y.; Yang, B.; Isolauri, E.; Salminen, S.; et al. Human Breast Milk NMR Metabolomic Profile across Specific Geographical Locations and Its Association with the Milk Microbiota. Nutrients 2018, 10, 1355. [CrossRef] [PubMed]

65. Collado, M.; Vinderola, G.; Salminen, S. Postbiotics: Facts and open questions. A position paper on the need for a consensus definition. Benef. Microbes 2019, 10, 711-719. [CrossRef] [PubMed]

66. Moossavi, S.; Sepehri, S.; Robertson, B.; Bode, L.; Goruk, S.; Field, C.J.; Lix, L.M.; De Souza, R.J.; Becker, A.B.; Mandhane, P.J.; et al. Composition and Variation of the Human Milk Microbiota Are Influenced by Maternal and Early-Life Factors. Cell Host Microbe 2019, 25, 324-335.e4. [CrossRef] [PubMed]

67. Wiciński, M.; Sawicka, E.; Gębalski, J.; Kubiak, K.; Malinowski, B. Human Milk Oligosaccharides: Health Benefits, Potential Applications in Infant Formulas, and Pharmacology. Nutrients 2020, 12, 266. [CrossRef]

68. Seppo, A.E.; Kukkonen, A.K.; Kuitunen, M.; Savilahti, E.; Yonemitsu, C.; Bode, L.; Järvinen, K.M. Association of Maternal Probiotic Supplementation With Human Milk Oligosaccharide Composition. JAMA Pediatr. 2019, 173, 286. [CrossRef]

69. Hill, C.; Guarner, F.; Reid, G.; Gibson, G.R.; Merenstein, D.J.; Pot, B.; Morelli, L.; Canani, R.B.; Flint, H.J.; Salminen, S.; et al. The International Scientific Association for Probiotics and Prebiotics consensus statement on the scope and appropriate use of the term probiotic. Nat. Rev. Gastroenterol. Hepatol. 2014, 11, 506-514. [CrossRef]

70. Gibson, G.R.; Hutkins, R.; Sanders, M.E.; Prescott, S.L.; Reimer, R.A.; Salminen, S.J.; Scott, K.; Stanton, C.; Swanson, K.S.; Cani, P.D.; et al. Expert consensus document: The International Scientific Association for Probiotics and Prebiotics (ISAPP) consensus statement on the definition and scope of prebiotics. Nat. Rev. Gastroenterol. Hepatol. 2017, 14, 491-502. [CrossRef]

71. De Vrese, M.; Schrezenmeir, J. Probiotics, Prebiotics, and Synbiotics. Plant Cells 2008, 111, 1-66. [CrossRef]

72. Salminen, S.; Szajewska, H.; Knol, J. The Biotics Family in Early Life; John Wiley and Sons Ltd.: Chichester, UK, 2019. 
73. O'Toole, P.W.; Marchesi, J.R.; Hill, C. Next-generation probiotics: The spectrum from probiotics to live biotherapeutics. Nat. Microbiol. 2017, 2, 17057. [CrossRef]

74. Braegger, C.; Chmielewska, A.; Decsi, T.; Kolaček, S.; Mihatsch, W.; Moreno, L.; Pieścik, M.; Puntis, J.; Shamir, R.; Szajewska, H.; et al. Supplementation of Infant Formula With Probiotics and/or Prebiotics: A Systematic Review and Comment by the ESPGHAN Committee on Nutrition. J. Pediatr. Gastroenterol. Nutr. 2011, 52, 238-250. [CrossRef]

75. Akker, C.H.V.D.; Van Goudoever, J.B.; Shamir, R.; Domellöf, M.; Embleton, N.D.; Hojsak, I.; Lapillonne, A.; Mihatsch, W.A.; Canani, R.B.; Bronsky, J.; et al. Probiotics and Preterm Infants: A Position Paper by the ESPGHAN Committee on Nutrition and the ESPGHAN Working Group for Probiotics and Prebiotics. J. Pediatr. Gastroenterol. Nutr. 2020, 70, 664-680. [CrossRef]

76. Miqdady, M.; Al Mistarihi, J.; Azaz, A.; Rawat, D. Prebiotics in the Infant Microbiome: The Past, Present, and Future. Pediatr. Gastroenterol. Hepatol. Nutr. 2020, 23, 1-14. [CrossRef] [PubMed]

77. Boehm, G.; Fanaro, S.; Jelinek, J.; Stahl, B.; Marini, A. Prebiotic concept for infant nutrition. Acta Paediatr. 2003, 92, 64-67. [CrossRef] [PubMed]

78. Boehm, G.; Moro, G. Structural and Functional Aspects of Prebiotics Used in Infant Nutrition. J. Nutr. 2008, 138, 1818S-1828S. [CrossRef] [PubMed]

79. Moro, G.; Boehm, G. Clinical Outcomes of Prebiotic Intervention Trials during Infancy: A Review. Funct. Food Rev. 2012, 4, 101-113. [CrossRef]

80. European Union. Ec. Commission Delegated Regulation (EU) 2016/127. Off. J. Eur. Union 2016, 127, L25.

81. Bych, K.; Mikš-Krajnik, M.; Johanson, T.; Hederos, M.J.; Vigsnæs, L.K.; Becker, P. Production of HMOs using microbial hosts-From cell engineering to large scale production. Curr. Opin. Biotechnol. 2019, 56, 130-137. [CrossRef]

82. Thurl, S.; Offermanns, J.; Müller-Werner, B.; Sawatzki, G. Determination of neutral oligosaccharide fractions from human milk by gel permeation chromatography. J. Chromatogr. B Biomed. Sci. Appl. 1991, 568, 291-300. [CrossRef]

83. Obermeier, S.; Rudloff, S.; Pohlentz, G.; Lentze, M.J.; Kunz, C. Secretion of 13 C-Labelled Oligosaccharides into Human Milk and Infant's Urine after an Oral 13 C-Galactose Load. Isot. Environ. Health Stud. 1999, 35, 119-125. [CrossRef]

84. Thurl, S.; Henker, J.; Taut, H.; Tovar, K.; Sawatzki, G. Variations of neutral oligosaccharides and lactose in human milk during the feeding. Eur. J. Nutr. 1993, 32, 262-269. [CrossRef]

85. Zeuner, B.; Teze, D.; Muschiol, J.; Meyer, A.S. Synthesis of Human Milk Oligosaccharides: Protein Engineering Strategies for Improved Enzymatic Transglycosylation. Molecules 2019, 24, 2033. [CrossRef]

86. Craft, K.M.; Townsend, S.D. Synthesis of lacto-N-tetraose. Carbohydr. Res. 2017, 43-50. [CrossRef]

87. Fair, R.J.; Hahm, H.S.; Seeberger, P.H. Combination of automated solid-phase and enzymatic oligosaccharide synthesis provides access to $\alpha(2,3)$-sialylated glycans. Chem. Commun. 2015, 51, 6183-6185. [CrossRef] [PubMed]

88. Lai, C.-H.; Hahm, H.S.; Liang, C.-F.; Seeberger, P.H. Automated solid-phase synthesis of oligosaccharides containing sialic acids. Beilstein J. Org. Chem. 2015, 11, 617-621. [CrossRef] [PubMed]

89. Walsh, C.; Lane, J.A.; Van Sinderen, D.; Hickey, R.M. From lab bench to formulated ingredient: Characterization, production, and commercialization of human milk oligosaccharides. J. Funct. Foods 2020, 72, 104052. [CrossRef]

90. Baumgärtner, F.; Seitz, L.; Sprenger, G.A.; Albermann, C. Construction of Escherichia coli strains with chromosomally integrated expression cassettes for the synthesis of 2 '-fucosyllactose. Microb. Cell Factories 2013, 12, 40. [CrossRef] [PubMed]

91. Baumgartner, F.; Conrad, J.; Sprenger, G.A.; Albermann, C. Synthesis of the Human Milk Oligosaccharide Lacto-N-Tetraose in Metabolically Engineered, Plasmid-Free E. coli. ChemBioChem 2014, 15, 1896-1900. [CrossRef]

92. Sprenger, G.A.; Baumgärtner, F.; Albermann, C. Production of human milk oligosaccharides by enzymatic and whole-cell microbial biotransformations. J. Biotechnol. 2017, 258, 79-91. [CrossRef]

93. Vandenplas, Y.; Berger, B.; Carnielli, V.P.; Książyk, J.; Lagström, H.; Sánchez-Luna, M.; Migacheva, N.; Mosselmans, J.-M.; Picaud, J.-C.; Possner, M.; et al. Human Milk Oligosaccharides: 2'-Fucosyllactose (2'-FL) and Lacto-N-Neotetraose (LNnT) in Infant Formula. Nutrients 2018, 10, 1161. [CrossRef] 
94. EFSA Panel on Dietetic Products, Nutrition and Allergies. Safety of lacto-N-neotetraose as a novel food ingredient pursuant to Regulation (EC) No 258/97. EFSA J. 2015, 13, 4183. [CrossRef]

95. EFSA Panel on Nutrition, Novel Foods and Food Allergens. Safety of lacto-N-tetraose (LNT) as a novel food pursuant to Regulation (EU) 2015/2283. EFSA J. 2019, 17, e05907. [CrossRef]

96. EFSA Panel on Nutrition, Novel Foods and Food Allergens. Safety of 2 '-fucosyllactose/difucosyllactose mixture as a novel food pursuant to Regulation (EU) 2015/2283. EFSA J. 2019, 17, e05717. [CrossRef]

97. FDA. U.S. Food \& Drug Administration GRAS Notices. Available online: https://www.accessdata.fda.gov/ scripts/fdcc/?set=GRASNotices (accessed on 18 February 2020).

98. Marcobal, A.; Barboza, M.; Froehlich, J.W.; Block, D.E.; German, J.B.; Lebrilla, C.B.; Mills, D.A. Consumption of Human Milk Oligosaccharides by Gut-Related Microbes. J. Agric. Food Chem. 2010, 58, 5334-5340. [CrossRef] [PubMed]

99. Asakuma, S.; Hatakeyama, E.; Urashima, T.; Yoshida, E.; Katayama, T.; Yamamoto, K.; Kumagai, H.; Ashida, H.; Hirose, J.; Kitaoka, M. Physiology of Consumption of Human Milk Oligosaccharides by Infant Gut-associated Bifidobacteria*. J. Boil. Chem. 2011, 286, 34583-34592. [CrossRef] [PubMed]

100. Yu, Z.-T.; Nanthakumar, N.N.; Newburg, D. The Human Milk Oligosaccharide 2'-Fucosyllactose Quenches Campylobacter jejuni-Induced Inflammation in Human Epithelial Cells HEp-2 and HT-29 and in Mouse Intestinal Mucosa. J. Nutr. 2016, 146, 1980-1990. [CrossRef]

101. Ruiz-Palacios, G.M.; Cervantes, L.E.; Ramos, P.; Chavez-Munguia, B.; Newburg, D.S. Campylobacter jejuniBinds Intestinal $\mathrm{H}(\mathrm{O})$ Antigen (Fuc $\alpha 1,2 \mathrm{Gal} \beta 1,4 \mathrm{GlcNAc}$ ), and Fucosyloligosaccharides of Human Milk Inhibit Its Binding and Infection. J. Boil. Chem. 2003, 278, 14112-14120. [CrossRef] [PubMed]

102. Weichert, S.; Jennewein, S.; Hüfner, E.; Weiss, C.; Borkowski, J.; Putze, J.; Schroten, H. Bioengineered 2 '-fucosyllactose and 3-fucosyllactose inhibit the adhesion of Pseudomonas aeruginosa and enteric pathogens to human intestinal and respiratory cell lines. Nutr. Res. 2013, 33, 831-838. [CrossRef] [PubMed]

103. Mezoff, E.A.; Hawkins, J.A.; Ollberding, N.J.; Karns, R.; Morrow, A.L.; Helmrath, M.A. The human milk oligosaccharide 2 -fucosyllactose augments the adaptive response to extensive intestinal. Am. J. Physiol. Liver Physiol. 2015, 310, G427-G438. [CrossRef]

104. Bienenstock, J.; Buck, R.H.; Linke, H.; Forsythe, P.; Stanisz, A.M.; Kunze, W.A. Fucosylated but Not Sialylated Milk Oligosaccharides Diminish Colon Motor Contractions. PLoS ONE 2013, 8, e76236. [CrossRef]

105. Azagra-Boronat, I.; Massot-Cladera, M.; Knipping, K.; Land, B.V.; Stahl, B.; Garssen, J.; Rodríguez-Lagunas, M.J.; Franch, À.; Castell, M.; Pérez-Cano, F.J. Supplementation With 2'-FL and scGOS/lcFOS Ameliorates Rotavirus-Induced Diarrhea in Suckling Rats. Front. Cell Infect. Microbiol. 2018, 8, 372. [CrossRef] [PubMed]

106. Elsen, L.V.D.; Tims, S.; Jones, A.; Stewart, A.; Stahl, B.; Garssen, J.; Knol, J.; Forbes-Blom, E.; Land, B.V. Prebiotic oligosaccharides in early life alter gut microbiome development in male mice while supporting influenza vaccination responses. Benef. Microbes 2019, 10, 279-291. [CrossRef] [PubMed]

107. Prieto, P.A. In Vitro and Clinical Experiences with a Human Milk Oligosaccharide, Lacto-NneoTetraose, and Fructooligosaccharides. Foods Food Ingred. J. Jpn. 2005, 210, 1018-1030.

108. Huang, X.; Zhu, B.; Jiang, T.; Yang, C.; Qiao, W.; Hou, J.; Han, Y.; Xiao, H.; Chen, L. Improved Simple Sample Pretreatment Method for Quantitation of Major Human Milk Oligosaccharides Using Ultrahigh Pressure Liquid Chromatography with Fluorescence Detection. J. Agric. Food Chem. 2019, 67, 12237-12244. [CrossRef]

109. He, Y.; Liu, S.; Leone, S.; Newburg, D. Human colostrum oligosaccharides modulate major immunologic pathways of immature human intestine. Mucosal Immunol. 2014, 7, 1326-1339. [CrossRef]

110. Varasteh, S.; Van't Land, B.; Giziakis, I.; Mank, M.; Stahl, B.; Wiertsema, S.; Folkerts, G.; Garssen, J.; Braber, S. Human Milk Oligosaccharide 3'-galactosyllactose Can Protect the Intestinal Barrier to Challenges. J. Pediatr. Gastroenterol. Nutr. 2019, 68, N-P-016.

111. Akbari, P.; Braber, S.; Alizadeh, A.; Verheijden, K.; Schoterman, M.H.; Kraneveld, A.D.; Garssen, J.; Fink-Gremmels, J. Galacto-oligosaccharides Protect the Intestinal Barrier by Maintaining the Tight Junction Network and Modulating the Inflammatory Responses after a Challenge with the Mycotoxin Deoxynivalenol in Human Caco-2 Cell Monolayers and B6C3F1 Mice. J. Nutr. 2015, 145, 1604-1613. [CrossRef]

112. Van De Heijning, B.J.M.; Berton, A.; Bouritius, H.; Goulet, O. GI Symptoms in Infants Are a Potential Target for Fermented Infant Milk Formulae: A Review. Nutrients 2014, 6, 3942-3967. [CrossRef]

113. Lemaire, M.; Luron, I.; Blat, S. Effects of infant formula composition on long-term metabolic health. J. Dev. Orig. Health Dis. 2018, 9, 573-589. [CrossRef] 
114. Pabst, O.; Mowat, A.M. Oral tolerance to food protein. Mucosal Immunol. 2012, 5, 232-239. [CrossRef]

115. Weiner, H.L. Oral tolerance, an active immunologic process mediated by multiple mechanisms. J. Clin. Investig. 2000, 106, 935-937. [CrossRef]

116. Arrieta, M.-C.; Stiemsma, L.T.; Amenyogbe, N.; Brown, E.M.; Finlay, B.B. The Intestinal Microbiome in Early Life: Health and Disease. Front. Immunol. 2014, 5, 427. [CrossRef] [PubMed]

117. Chua, M.C.; Ben-Amor, K.; Lay, C.; Goh, A.E.; Chiang, W.C.; Rao, R.; Chew, C.; Chaithongwongwatthana, S.; Khemapech, N.; Knol, J.; et al. Effect of Synbiotic on the Gut Microbiota of Cesarean Delivered Infants: A Randomized, Double-blind, Multicenter Study. J. Pediatr. Gastroenterol. Nutr. 2017, 65, 102-106. [CrossRef] [PubMed]

118. Abrahamse-Berkeveld, M.; Alles, M.; Franke-Beckmann, E.; Helm, K.; Knecht, R.; Köllges, R.; Sandner, B.; Knol, J.; Ben Amor, K.; Bufe, A. Infant formula containing galacto-and fructo-oligosaccharides and Bifidobacterium breve M-16V supports adequate growth and tolerance in healthy infants in a randomised, controlled, double-blind, prospective, multicentre study. J. Nutr. Sci. 2016, 5. [CrossRef]

119. Van Der Aa, L.B.; Heymans, H.S.; Van Aalderen, W.M.; Smitt, J.H.S.; Knol, J.; Ben Amor, K.; Goossens, D.A.; Sprikkelman, A.B. Effect of a new synbiotic mixture on atopic dermatitis in infants: A randomized-controlled trial. Clin. Exp. Allergy 2010, 40, 795-804. [CrossRef]

120. Van Der Aa, L.B.; Van Aalderen, W.M.C.; Heymans, H.S.A.; Smitt, J.H.S.; Nauta, A.J.; Knippels, L.M.J.; Ben Amor, K.; Sprikkelman, A.B.; The Synbad Study Group. Synbiotics prevent asthma-like symptoms in infants with atopic dermatitis. Allergy 2011, 66, 170-177. [CrossRef] [PubMed]

121. Aguilar-Toalá, J.; García-Varela, R.; Garcia, H.; Mata-Haro, V.; González-Córdova, A.; Vallejo-Cordoba, B.; Hernandez-Mendoza, A. Postbiotics: An evolving term within the functional foods field. Trends Food Sci. Technol. 2018, 75, 105-114. [CrossRef]

122. Sanders, M.E. Defining Emerging 'Biotics'. Available online: https://isappscience.org/defining-emergingbiotics/ (accessed on 23 March 2020).

123. Agostoni, C.; Goulet, O.; Kolacek, S.; Koletzko, B.; Moreno, L.; Puntis, J.; Rigo, J.; Shamir, R.; Szajewska, H.; Turck, D. Fermented Infant Formulae Without Live Bacteria. J. Pediatr. Gastroenterol. Nutr. 2007, 44, 392-397. [CrossRef]

124. Huet, F.; Abrahamse-Berkeveld, M.; Tims, S.; Simeoni, U.; Beley, G.; Savagner, C.; Vandenplas, Y.; Hourihane, J.O. Partly Fermented Infant Formulae With Specific Oligosaccharides Support Adequate Infant Growth and Are Well-Tolerated. J. Pediatr. Gastroenterol. Nutr. 2016, 63, e43-e53. [CrossRef]

125. Vandenplas, Y.; Ludwig, T.; Bouritius, H.; Alliet, P.; Forde, D.; Peeters, S.; Huet, F.; Hourihane, J. Randomised controlled trial demonstrates that fermented infant formula with short-chain galacto-oligosaccharides and long-chain fructo-oligosaccharides reduces the incidence of infantile colic. Acta Paediatr. 2017, 106, 1150-1158. [CrossRef]

126. Mischke, M.; Vincent, A.; Duchene, B.; Knol, J.; Van Seuningen, I.; Renes, I. Combination of Specific Pre-and Postbiotics in Infant Formula Induces Gut Barrier Maturation Closer to Mother's Milk and Supports Gut Functionality in Mice. J. Pediatr. Gastroenterol. Nutr. 2019, 68, N-O-011.

127. Sureda, E.A.; Gidlund, C.; Weström, B.; Prykhodko, O. Induction of precocious intestinal maturation in T-cell deficient athymic neonatal rats. World J. Gastroenterol. 2017, 23, 7531-7540. [CrossRef]

128. Brunser, O.; Araya, M.; Espinoza, J.; Guesry, P.R.; Secretin, M.C.; Pacheco, I. Effect of an Acidified Milk on Diarrhoea and the Carrier State in Infants of Low Socio-Economic Stratum. Acta Paediatr. 1989, 78, 259-264. [CrossRef] [PubMed]

129. Scholtens, P.A.; Oozeer, R.; Martín, R.; Ben Amor, K.; Knol, J. The Early Settlers: Intestinal Microbiology in Early Life. Annu. Rev. Food Sci. Technol. 2012, 3, 425-447. [CrossRef] [PubMed]

130. Tsilingiri, K.; Rescigno, M. Postbiotics: What else? Benef. Microbes 2013, 4, 101-107. [CrossRef] [PubMed]

131. Rojas, J.N.M.; Mantziari, A.; Salminen, S.; Szajewska, H. Postbiotics for Preventing and Treating Common Infectious Diseases in Children: A Systematic Review. Nutrients 2020, 12, 389. [CrossRef]

132. Mullié, C.; Yazourh, A.; Thibault, H.; Odou, M.-F.; Singer, E.; Kalach, N.; Kremp, O.; Romond, M.-B.; Mulli, C. Increased Poliovirus-Specific Intestinal Antibody Response Coincides with Promotion of Bifidobacterium longum-infantis and Bifidobacterium breve in Infants: A Randomized, Double-Blind, Placebo-Controlled Trial. Pediatr. Res. 2004, 56, 791-795. [CrossRef] [PubMed] 
133. Thibault, H.; Aubert-Jacquin, C.; Goulet, O. Effects of Long-term Consumption of a Fermented Infant Formula (with Bifidobacterium breve c50 and Streptococcus thermophilus 065) on Acute Diarrhea in Healthy Infants. J. Pediatr. Gastroenterol. Nutr. 2004, 39, 147-152. [CrossRef] [PubMed]

134. Indrio, F.; Ladisa, G.; Mautone, A.; Montagna, O. Effect of a Fermented Formula on Thymus Size and Stool pH in Healthy Term Infants. Pediatr. Res. 2007, 62, 98-100. [CrossRef] [PubMed]

135. Campeotto, F.; Suau, A.; Kapel, N.; Magne, F.; Viallon, V.; Ferraris, L.; Waligora-Dupriet, A.-J.; Soulaines, P.; Leroux, B.; Kalach, N.; et al. A fermented formula in pre-term infants: Clinical tolerance, gut microbiota, down-regulation of faecal calprotectin and up-regulation of faecal secretory IgA. Br. J. Nutr. 2011, 105, 1843-1851. [CrossRef]

136. Morisset, M.; Aubert-Jacquin, C.; Soulaines, P.; Moneret-Vautrin, D.-A.; Dupont, C. A non-hydrolyzed, fermented milk formula reduces digestive and respiratory events in infants at high risk of allergy. Eur. J. Clin. Nutr. 2010, 65, 175-183. [CrossRef] [PubMed]

137. Tims, S.; Roeselers, G.; Knol, K. Gut Microbiota Composition Modulation by Partly Fermented Infant Formulae Supplemented with Prebiotics, scGOS/lcFOS. J. Pediatr. Gastroenterol. Nutr. 2018, 66, N-eP-029.

(C) 2020 by the authors. Licensee MDPI, Basel, Switzerland. This article is an open access article distributed under the terms and conditions of the Creative Commons Attribution (CC BY) license (http://creativecommons.org/licenses/by/4.0/). 